\title{
Is Medicine Just a DREAM for DACA Students? DACA Practices and Policies Among U.S. Medical Schools
}

\author{
Sara Carranco $^{1} \cdot$ Olveen Carrasquillo $^{1} \cdot{\text { BreAnne } \text { Young }^{1} \text { (i) } \cdot \text { Sonjia Kenya }}^{1}$ \\ Accepted: 29 April 2021 / Published online: 27 May 2021 \\ (c) The Author(s), under exclusive licence to Springer Science+Business Media, LLC, part of Springer Nature 2021
}

\begin{abstract}
As of 2020, 75 accredited institutions with the Association of American Medical Colleges (AAMC) are described as "DACAfriendly" and welcome undocumented students to apply under the Deferred Action for Childhood Arrivals (DACA) program. However, there is wide variation in their DACA policies, complicating an already demanding application process. Herein, we discuss this process and the common challenges for DACA-recipients. From September 2018 to July 2019, a three-item survey was emailed to admissions representatives at DACA-accepting institutions. While all participating universities were familiar with DACA, only $58 \%$ of representatives were aware of their institutional policies. Further, less than $10 \%$ of schools reserved funds for DACA-recipients; some required proof of payment for all 4 years prior to matriculation. The number of "DACA-friendly" institutions having enrolled DACA students is limited. Open promotion of institutional DACA policies may increase the number of recipients that successfully complete US medical training.
\end{abstract}

Keywords Medical education · Policy · Admissions · Immigration · Deferred Action for Childhood Arrivals (DACA)

\section{Introduction}

Established in 2012, the Deferred Action for Childhood Arrivals (DACA) program protects undocumented immigrants who entered the U.S. as children from deportation. Enacted in response to the setbacks experienced by the Development, Relief and Education for Alien Minors (DREAM) Act, DACA offers work authorization and other benefits for individuals who are enrolled in high school or graduated and have not been convicted of major offenses [1]. Often referred to as DREAMers-a term coined from the original bill - there have been over 767,000 DACA recipients since the executive order was issued in 2012 [2, 3]. Courts across the nation, including the U.S. Supreme Court, have blocked attempts by the federal government to phase out the program over the last 3 years, ultimately citing insufficient justification to end DACA in their rulings [4]. In support of the program were several states, universities, and over 140 companies testifying on the important contributions of DACA recipients to the country and the economy.

BreAnne Young

b.young4@umiami.edu

1 Department of Medicine, University of Miami Miller School of Medicine, Miami, FL 33136, USA
Organized medicine has also been a strong supporter of DACA. In 2018, the Association of American Medical Colleges (AAMC) filed an amicus brief on behalf of 33 health professional organizations-including the American Medical Association and the Federation of American Hospitals-in support of DACA [5]. By May 2020, the number had increased to 77 health professions organizations, noting that approximately 30,000 DACA recipients were currently working on the front lines to fight COVID-19 [6]. However, until recently many medical schools considered applicants with DACA status as international rather than domestic students. In 2012, the Loyola University of Chicago Stritch School of Medicine became the first U.S. medical school to recognize applicants with DACA status as domestic students. In 2015 there were 16 such schools [7]. By 2020, of the 160 schools listed on AAMC's Medical School Admissions Requirements (MSAR) database, 75 were described as "DACA-friendly" institutions, of which $44 \%$ were private and $56 \%$ public [7].

Despite this designation, students seeking information on DACA admissions policies anecdotally report receiving conflicting answers from different individuals at the same institution [8]. This wide variation in DACA policies among medical schools further complicates the already demanding medical school application process for DACA students. To 
obtain basic information about policies governing admissions for DACA students, we conducted a brief survey among DACA-friendly U.S. medical schools.

\section{Methods}

Seventy-five medical schools were identified as potential participants using the AAMC's MSAR database; specifically, institutions designated on MSAR as "DACA-friendly" were eligible to participate. "DACA-friendly" designation is self-identified by each medical school at the discretion of the institution. The determination is often based on institutional policy and state laws that restrict eligibility for admission or in-state tuition for undocumented students [9]. Contact information for persons within the admissions office and office of diversity for each DACA-friendly school was obtained from the institution's admissions website, as these two offices were believed to be most likely to have knowledge on such policies. Prior to contacting the schools, this study was reviewed by the University of Miami Institutional Review Board, which determined that no further approval was needed.

From September 2018 to July 2019, the contact person at each DACA-friendly medical school was sent an email from a University of Miami student using an institutional email account. In the email, three open-ended questions were asked on knowledge of DACA, financial aid for DACA students, and prior experience with DACA students (see Table 1). Recipients were told the survey was a research project to learn about medical school admissions policies for DACA students. If recipients felt they were not the best person to answer the questions, they were asked for the name of another person more suited to respond. For schools that did not initially respond, a reminder email was sent a few months later.

\section{Results}

As seen in Table 1, of the 75 medical schools, 33 replied to the email, two declined to participate, and 40 did not reply. All respondents noted familiarity with the DACA program but only 58\% were aware of their institutional financial aid policies for DACA students. Of those citing financial aid policies, thirteen noted financial aid was available for all students. A small number of institutions had limited funding for DACA students; however, these funds were limited, and students were expected to identify additional sources of needs-based funding if DACA funds were no longer available. Some medical schools also required applicants to provide proof of payment for all 4 years in advance of

Table 1 Survey items \& results from the DACA Admissions Questionnaire

\begin{tabular}{|c|c|c|}
\hline \multicolumn{3}{|l|}{ Admissions Request for Participation Script } \\
\hline \multicolumn{3}{|c|}{$\begin{array}{l}\text { Good Morning, this is } \ldots \text {. I am a student from the University of Miami. I am doing a school research project to learn about medical school } \\
\text { admissions policies for DACA students, and } \overline{\text { has been identified as a DACA Friendly institution. The information collected from }} \\
\text { each school will be used to inform future DACA applicants. }\end{array}$} \\
\hline \multicolumn{3}{|c|}{$\begin{array}{l}\text { If you are not the best person to answer these questions, who should I speak to? Is there any additional information you would like DACA stu- } \\
\text { dents to know when applying to your medical school? }\end{array}$} \\
\hline \multicolumn{3}{|l|}{ Thank you again for your participation! } \\
\hline \multicolumn{3}{|l|}{ DACA Admissions Questionnaire } \\
\hline \multicolumn{3}{|l|}{ 1. Do you know what DACA is? (If yes, explain) } \\
\hline \multicolumn{3}{|c|}{$\begin{array}{l}\text { 2. According to the AAMC, you have a policy regarding DACA students. Is that correct? Can you describe the policy? (Eligibility, financial } \\
\text { aid given, living expenses, in-state vs. out-of-state awards, needs-based vs. merit-based, ; etc.) }\end{array}$} \\
\hline \multicolumn{3}{|c|}{ 3. Do you have any DACA students currently enrolled? If so, can you estimate about how many? } \\
\hline DACA Admissions Questionnaire Results & $n$ & \\
\hline \multicolumn{3}{|l|}{ Eligible Institutions $(\mathrm{n}=75)$} \\
\hline Responded to survey & 33 & $44 \%$ \\
\hline Did not responded & 40 & $53 \%$ \\
\hline Declined to participate & 2 & $3 \%$ \\
\hline \multicolumn{3}{|l|}{ Response to Questions $(n=33)$} \\
\hline 1. Had Knowledge of DACA & 33 & $100 \%$ \\
\hline \multicolumn{3}{|c|}{ 2. Had Knowledge of Institutional Financial Aid Policies for DACA students } \\
\hline Knowledge of policies & 19 & $58 \%$ \\
\hline Needs-/merit-based funding available for all applicants & 13 & $39 \%$ \\
\hline Funding available for DACA students only & 4 & $12 \%$ \\
\hline 3. Has DACA students currently enrolled & 11 & $33 \%$ \\
\hline
\end{tabular}


matriculation. Only one-third of schools had previously enrolled DACA students.

\section{Discussion}

While more schools are becoming DACA-friendly, this study found the number of schools having actually enrolled DACA students is limited. These findings are consistent with the AAMC estimate of only 200 medical students and residents that have benefitted from the DACA that over the last 8 years; for comparison, 1 st-year enrollment in U.S. medical schools is approximately 20,000 students $[5,7]$.

While current laws do not prevent DACA students from earning an education, ambivalence from many institutions on the socioeconomic barriers to a college education serve as a deterrent to higher learning. DACA recipients are ineligible for federal aid [8], which is used by the majority of students to finance their medical education. Some institutions further required financial commitments that are unfeasible for most medical students, regardless of immigration status. Thus, having funding streams to help DACA students is key to helping them become physicians. Working with local government, financial agencies, and private donors to secure additional funding demonstrates a commitment to increasing access to medical education for students of any socioeconomic background.

To date, less that $0.1 \%$ of the 800,000 individuals awarded DACA status have gone on to train at U.S. medical schools [10-12]. Many of these aspiring physicians will work in some of the Nation's most underserved regions, much like the international medical graduates (IMG) who receive specialty training in the U.S. but completed their medical education abroad. One out of four physicians in the U.S. is an IMG, nearly a third of whom specialize in family practice or internal medicine [11].

With the increasing racial diversity of the nation's patient population, IMGs are able to provide patients with a culturally- or racially-concordant provider, which fosters increased patient trust and encourages treatment adherence [13]. Research further suggests IMGs generally generate greater patient satisfaction and better patient outcomes compared to U.S. medical graduates due to the variation in their cultural experiences [14]. The number of IMGs supporting the U.S. healthcare infrastructure has surged in recent years, increasing by nearly $18 \%$ since 2010 [15]. Yet even with this growth in the field, the current ratio of patient to primary care provider is 1463 to 1 [16].

Similar to IMGs, DACA students are a promising yet relatively untapped demographic with the potential to achieve comparable outcomes in the healthcare field. While additional research is needed to determine how DACA students can fill the gaps in healthcare delivery, current data suggests they will serve the areas of greatest need. This knowledge, partnered with an understanding of the health inequities experienced by ethno-racial minorities, highlights the important role DACA students could serve towards ameliorating health disparities if granted clear opportunities for medical school admission.

\section{Limitations}

Given the divisive political climate at the time this survey was distributed, some schools may have felt uncomfortable or constrained in revealing too much about their DACA policies. This may help explain the low response rate or why many respondents did not provide information about their financial aid policies for such students. A more personalized approach rather than email may have resulted in more detailed answers. In addition, it is possible that some schools may have never admitted a DACA student, and thus have not needed to address some of the issues discussed in the survey, such as financial aid.

This study also used a simple three-item survey to query the admissions policies for DACA students applying to U.S. medical schools. As such, the data collected can only provide introductory information on the resources and challenges surrounding the application process for DACA students. Future studies using more structured assessments should be used to form a clearer understanding of the types of institutions accepting DACA recipients.

\section{Conclusions}

Ultimately, our findings suggest that despite the tremendous political support for DACA by organized medicine, medical schools could do more to help students in their application process, specifically by providing clearer viewpoints and guidance on the financial aid resources and admission processes for undocumented applicants. This could include the development of a dedicated landing page for DACA-specific content on the school website or hiring admissions and financial aid officers that are expressly dedicated to addressing the needs of undocumented applicants and matriculants. Schools could further create safe spaces for existing DACA students to voice concerns or seek mentorship as a way of further establishing commitment to diversity and inclusion as part of the institutional culture. Finally, the development of uniform requirements for "DACA-friendly" designation with the AAMC would significantly benefit medical schools and their prospective applicants by creating standardized guidelines, saving time and resources for students and the admissions committees. 
Substantial evidence suggests the U.S. medical workforce would greatly benefit from the participation of more immigrant physicians, a role DACA students could potentially fulfil. In the midst of the Nation's growing shortage of primary care providers are these aspiring physicians, many of whom reflect the same ethnoracial characteristics shared by the rural and underserved communities lacking healthcare access across the U.S. $[17,18]$. As the racial diversity of the Nation's patient population continues to grow, increasing the number of DREAMers in our physician workforce is a promising approach to advance health equity among culturally-distinct populations in America.

Funding This project was reviewed by the University of Miami Institutional Review Board and was designated as not human subjects research (IRB ID: 20181205).

\section{Declarations}

Conflict of interest No financial disclosures or conflicts of interest were reported by the authors of this paper.

\section{References}

1. Department of Homeland Security. Deferred action for childhood arrivals: who can be considered?. [Internet]. 2012. Available at: https://www.dhs.gov/blog/2012/08/15/deferred-action-childhoodarrivals-who-can-be-considered.

2. Anti-Defamation League. What is the dream act and who are the dreamers?. [Internet]. 2021. Available at: https://www.adl.org/ education/educator-resources/lesson-plans/what-is-the-dreamact-and-who-are-the-dreamers.

3. U.S. Citizenship and Immigration Services. Approximate active DACA recipients: March 2020. [Internet]. 2020. Available at: https://www.uscis.gov/sites/default/files/USCIS/Resources/Repor ts\%20and\%20Studies/Immigration\%20Forms\%20Data/Static_ files/DACA_Population_Receipts_since_Injunction_Jun_30_ 2019.pdf.

4. Department of Homeland Security v. Regents of the University of California, 2020 WL 3271746 (2020). [Internet]. 2020. Available at: https://www.supremecourt.gov/opinions/19pdf/18-587_ 5ifl.pdf.

5. Brief Amicus Curiae of the National Education Association, et al., in Support of Respondents. [Internet]. 2019. Available at: https:// www.aamc.org/system/files/2019-10/ocomm-ogr-DACA\%20Ami cus\%20Brief-10082019.pdf.
6. DACA Physicians Serve on COVID-19 Front Lines. [Internet]. 2020. Available at: https://www.aamc.org/news-insights/dacaphysicians-serve-covid-19-front-lines.

7. Associate of American Medical Colleges. Medical School Admission Requirements (MSAR) Guide. [Internet]. 2020. Available at: https://apps.aamc.org/msar-ui/\#/landing.

8. Casas JB, Benuto LT, Newlands R. The educational experiences of DACA recipients. J Latinos Educ. 2019;24:1-6.

9. Cook S, Gaylord I. Navigating graduate school: resource guide for undocumented students. [Internet]. 2018. Immigration Law \& Policy Practicum Projects. 1. Available at: https://digitalcom mons.law.scu.edu/stu-immigration/1.

10. Anaya YB, del Rosario M, Doyle LH, Hayes-Bautista DE. Undocumented students pursuing medical education: the implications of deferred action for childhood arrivals (DACA). Acad Med. 2014;89(12):1599-602.

11. López G, Krogstad JM. Key facts about unauthorized immigrants enrolled in DACA. [Internet]. 2017. Pew Research Center. Available at: https://www.pewresearch.org/fact-tank/2017/09/25/keyfacts-about-unauthorized-immigrants-enrolled-in-daca/.

12. Nakae S, Marquez DR, Di Bartolo IM, Rodriguez R. Considerations for residency programs regarding accepting undocumented students who are DACA recipients. Acad Med. 2017;92(11):1549-54.

13. Fitzgerald $\mathrm{C}$, Hurst $\mathrm{S}$. Implicit bias in healthcare professionals: a systematic review. BMC Med Ethics. 2017. https://doi.org/10. 1186/s12910-017-0179-8.

14. Braveman PA, Kumanyika S, Fielding J, LaVeist T, Borrell LN, Manderscheid R, Troutman A. Health disparities and health equity: the issue is justice. Am J Public Health. 2011;101(S1):S149-55.

15. Ranasinghe PD. International medical graduates in the US Physician Workforce. J Am Osteopath Assoc. 2015;115(4):236.

16. Murphy B. How IMGs have changed the face of American medicine. [Internet]. 2021. American Medical Association. Available at: https://www.ama-assn.org/education/international-medicaleducation/how-imgs-have-changed-face-american-medicine.

17. Kuczewski MG, Brubaker L. Medical education for "Dreamers": barriers and opportunities for undocumented immigrants. Acad Med. 2014;89(12):1593-8.

18. National Center for Health Workforce Analysis. 2016. State-Level Projections of Supply and Demand for Primary Care Practitioners: 2013-2025. [Internet]. 2016. U.S. Department of Health and Human Servives. Available at: https://bhw.hrsa.gov/sites/default/ files/bureau-health-workforce/data-research/primary-care-stateprojections2013-2025.pdf.

Publisher's Note Springer Nature remains neutral with regard to jurisdictional claims in published maps and institutional affiliations. 